\title{
Quine's Ontology and the Islamic Tradition
}

\author{
Abbas Ahsan
}

\begin{abstract}
Analytic theologians seem to unreservedly prioritize a realist view in the way they approach theological dogmas. I have previously argued that this particular type of realist methodological approach is inconsistent with the Islamic tradition. I demonstrated that this inconsistency lies between two primary theses which constitute realism and an absolutely transcendent and ineffable God of the Islamic tradition. I had established how each of these theses proved responsible, in different ways, for divesting the Islamic God of His absolute transcendence. In this paper I determine why this is the case. I primarily seek to explicate the underlying reason for why metaphysical (theological) realism proves to be responsible for stripping the Islamic God of His absolute transcendence. This would involve being able to stipulate, somewhat accurately, the precise source of the accentuated inconsistency between metaphysical (theological) realism and the Islamic understanding of an absolutely transcendent and ineffable God. The exact source of this inconsistency, I shall argue, is grounded in Quine's ontological theses, which underlie much of what metaphysical realism imports into the domain of analytic theology.
\end{abstract}

\section{Introduction}

Ever since logical positivism fell into decline from the 1950s onwards, and up until its stagnation in the 1970s, much effort has been invested in reviving philosophical theology. This project was to put right what the logical Abbas Ahsan is a doctoral researcher at the John Hick Centre for Philosophy of Religion at the University of Birmingham. His current research focuses on the methodology and the possible application of analytic philosophy in the Islamic tradition. He is particularly interested in exploring the application of Dialetheism, paraconsistent logics and formal theories of truth to Islamic theological paradoxes. 
positivists had so erroneously wronged. After academia had exerted much of its resentment against theological matters and religious discourse, it reprised such themes in a different light. This effort meant gradually contesting the logical positivists' outlook and reinstating the seriousness that theological matters deserved. It involved a concerted endeavor at breaking free from the shackles of contemporary empiricism while sharing a conviction that theological matters were not meaningless. We can glean a sense of this approach from the publication of New Essays in Philosophical Theology edited by Antony Flew and Alasdair MacIntyre in 1955. This volume acted as a catalyst for analytic philosophers to profoundly and dynamically engage in theological matters and religious discourse without the fear of being stigmatized as irrational in any loose sense. This was of course keenly received, in particular by figures who embraced this prospect as an opportunity to return a philosophical coherency to religion. This is reflected in the upsurge of interest in the discipline of analytic philosophy of religion since the 1980s.

The academic attention devoted to analytic philosophy of religion has attempted to shed intellectual light on age-old theological issues. In doing so it has undergone its own evolution-for example, in introducing 'analytic theology' as a contemporary method of philosophical practice. Analytic theology can be considered a successor of earlier methods practiced by theologians, but Crisp suggests that it is more properly seen as a contemporary 'faith seeking understanding' project. That is, analytic theology employs the tools of analytic philosophy in the service of theology. This would involve, as Crisp puts it, "adopting and adapting a rhetorical style, ambitions and vocabulary of analytic philosophy to properly theological ends" (Crisp 2011, 475).

The analytic theology that has received considerable attention-particularly in Analytic Theology: New Essays in the Philosophy of Theology, edited by Crisp and Rea (2009)—has been analytic Christian theology. ${ }^{1}$ Of course, this volume is not representative of the entire Christian tradition, but Crisp has interestingly suggested that "there is nothing preventing other theistic religions taking up and adapting much of the following to their own purposes. I suppose a Muslim might find much in an analytic theological method that is agreeable" (Crisp 2009, 43). Although Crisp seems to be merely expressing a possibility for other faiths (such as Islam) to take up what is on offer by analytic theology, I find this somewhat ambitious and imprecise. Islamic theology has received very little academic attention in 
this respect, compared with that of Christianity; there remain fundamental methodological questions that surround analytic theology, which may need to be addressed prior to embarking on an Islamic analytical theology. These questions may also be considered as 'predicaments' that determine how analytic theology ought to be characterized and, subsequently, how it ought to be done.

Many analytic theologians ${ }^{3}$ appear to adopt a realist view in the way they approach theological dogmas. ${ }^{4}$ Indeed, the realist view is one of the more prominent methodological modes (among others ${ }^{5}$ ) which analytic theologians have prioritized. ${ }^{6}$ My use of the term 'theological realists' specifically refers to theologians who espouse a realist outlook in the particular domain of analytic theology. In a previous work (Ahsan 2017) I have argued that although this particular theological-realist approach (or methodology) may prove to be amenable with various Christian doctrines and perhaps (in some respects) the Christian tradition as a whole, it is demonstrably inconsistent with an Islamic understanding of an absolutely transcendent and ineffable God. ${ }^{7}$ In the course of this argument, I segmented the theological-realist approach into two essential components. The first reason for doing so was to provide a definition that proved feasible in fulfilling the anticipated aim. The second was to ensure a degree of precision regarding how the constituting theses would correspond with a particular understanding of God in the Islamic tradition to which they were applied. Theological realism was thus presented as comprising metaphysical and epistemological components. I proposed that the former of these two theses professes a mind-independent reality which we could consider God to be either an occupant of or identical to. I suggested that the latter of these two theses professes an epistemic aptitude in being able to objectively know this mind-independent reality. ${ }^{8}$

Furthermore, the theological realism in question is constituted of two theses (namely metaphysical and epistemic). The former of these was further subdivided into two varieties. The mind-independent divine reality is one which either includes God or is identical with God. ${ }^{9}$ The first reading would present an understanding of God in which He is encompassed by this mind-independent reality, that is, He is contained in/by its parameters. The second reading would present an understanding of God in which $\mathrm{He}$ is homogenous with this mind-independent reality, resulting in a form of pantheism. ${ }^{10} \mathrm{I}$ demonstrated that both components of theological realism, namely its metaphysical and epistemological theses, are inconsistent with an Islamic understanding of a God that is absolutely transcendent and inef- 
fable. This also included demonstrating that this idea of God in the Islamic tradition proved inconsistent with both of the varieties of metaphysical realism. On the whole this inconsistency meant that both components which constitute a realist outlook (adopted by most analytic theologians) along with the two readings of metaphysical (theological) realism would fail to concur with an Islamic understanding of an absolute, transcendent, and ineffable God. The inconsistency inexorably divested this particular (understanding of the) Islamic God of His transcendence and demoted Him to the confines of the human mind and the operations of the human language. All of this was, as I established, owing to this philosophical commitment to theological realism.

In the current paper, I would like to extend my focus on the two possible readings that metaphysical (theological) realism was subdivided into. This extension would primarily seek to explicate the underlying reason for why the two possible readings of metaphysical (theological) realism have been demonstrated to be responsible for stripping the Islamic God of absolute transcendence. This would involve being able to reasonably stipulate the precise source of the accentuated inconsistency between metaphysical (theological) realism and the Islamic understanding of an absolutely transcendent and ineffable God. The exact source of this inconsistency, I shall argue, is grounded in Quine's ontological theses (outlook) which underlie metaphysical realism. This is to say that metaphysical (theological) realism is true only if Quine's ontological theses are true.

My argument is as follows:

P1 Quine's ontological theses (outlook) are a prerequisite of metaphysical realism (which underlies much of its methodological approach).

P2 Quine's ontological theses (outlook) are the source for the inconsistency between the two possible readings of metaphysical (theological) realism and the Islamic understanding of an absolute transcendent and ineffable God.

P3 In consequence, Quine's ontological theses (outlook) are themselves equally inconsistent with an Islamic understanding of an absolute transcendent and ineffable God.

In virtue of my argument I shall present this paper in four main sections. Sections one and two serve as a prelude, without which the stakes and force of my later argument cannot be fully appreciated. Hence the overly descrip- 
tive explication of these two sections. I hope to demonstrate P1 and P2 in section three, while section four shall conclude with P3. More specifically, I shall begin section one of this paper by presenting an outline of Russell and Quine's philosophy of language. I shall consider the opposing methods which both Russell and Quine adopted in addressing the fundamental epistemological question of our ability to know things. Subsequently, I shall draw a connection between Quine's selected method and his overarching naturalism. I will then elaborate on Quine's naturalistic attitude and explain how it influences his philosophy of language. More specifically, I shall express how his intellectual commitment to a naturalistic method in approaching language goes on to shape his ontological outlook. This shall be the topic of section two. I will present a synopsis of his ontological outlook based upon four of the five theses which Van Inwagen has offered, and explicate each one with an example. In section three of the paper I reiterate the two possible readings of metaphysical (theological) realism. Thereafter, I work through each of Quine's four ontological theses, demonstrating how each of them stands as an underlying cause from which any one or both of the readings of metaphysical (theological) realism can be inferred. This would illustrate how Quine's ontological theses are the source for the inconsistency between the two possible readings of metaphysical realism and the Islamic understanding of God. Towards the end of this section I shall respond to two objections that arise from the particular notion of God in the Islamic tradition that I consider. In the fourth and final section of this paper I conclude by affirming my argument, noting that it implies that Quine's ontological outlook is itself equally inconsistent with an Islamic 'analytic theology'.

It is first worth noting how Quine's ontology, more generally, bears significance to the Islamic tradition. Although this may appear to be a somewhat remote question with respect to contemporary ontological studies and Islamic orthodoxy, it is nonetheless important if we are to witness an engagement between contemporary modes of analytic philosophy and Islam. Moreover, questions of this nature shall assist us in being able to understand the degree of consistency, if any, between predominant ontological methods (in analytic philosophy) and Islamic theology.

Ontology, in the most generic sense, is the study of being; of what there is. Ontology, thus, concerns itself with attempting to distinguish what exists from what does not. It further entails understanding the concept of existence, that is, what it actually means to be. Any attempt to determine 
the existence and non-existence of an entity would hardly prove meaningful without knowing what it actually means for something to exist in the most general sense. Quine developed a new method for addressing such ontological questions in the mid-twentieth century, as primarily inspired by developments made in formal logic during the early part of that century. For Quine the task of ontology was to present a comprehensive catalogue of the furniture of the world. It was to present us with all that there is in a manner which ensures excluding what there is not. Quine proposed a method by which we should decide the kinds of entities we ought to believe in - that is to say, the kinds of entities that exist. Quine's method has since become a standard view within analytic philosophy. Although it has certainly not gone unchallenged, it has proven to be exceptionally popular amongst many contemporary metaphysicians. ${ }^{11}$

Given that Quine's method occupies a predominant position among metaphysicians, it deserves serious attention for our purposes, for matters concerning existence and reality play an integral role when it comes to theological matters (for instance, the existence and reality of God). The kind of ontological method which one adopts in turn determines the kind of understanding one arrives at with respect to matters pertaining to existence and reality. Analytic theologians, in this regard, have carried forward Quine's method in approaching various aspects of Christianity. Aside from whether this particular method actually succeeds or fails in being amenable to the Christian tradition, the important question for me is whether it proves amenable with the Islamic tradition. As previously noted, Crisp has indicated that "a Muslim might find much in an analytic theological method that is agreeable" (Crisp 2009, 43). I shall demonstrate that this is not the case. There are fundamental issues which reside in Quine's ontological method that prove to be at odds with the Islamic tradition.

\section{1: Russell and Quine on the Philosophy of Language}

An unavoidable preliminary to understanding Quine ${ }^{12}$ is that he was an unreserved naturalist. His commitment to naturalism was in essence a constitution of the following two theses: ${ }^{13}$

First, there is no successful first philosophy - that is, no experiential or a priori ground outside of science upon which science can be justified or rationally reconstructed. Second, it is up to science to tell us what there is and how we know what there is-that is, science is the measure of what 
there is (ontology) and of how we come to know what there is (epistemology). (Gibson 2004, 6)

Science, for Quine, is the ultimate arbiter which sets the groundwork for a 'physicalist ontology and an empiricist epistemology' ${ }^{14}$ For Quine, the term 'physicalism' ${ }^{15}$ carries connotations of a refined materialism ${ }^{16}$ over into various domains of philosophy, such as philosophy of language, ${ }^{17}$ philosophy of mind, ${ }^{18}$ and ontology. Although our primary focus here is Quine's ontology, the influences of his philosophy of language (in particular) and philosophy of mind cannot be disregarded. ${ }^{19}$ To appreciate this point, let us contrast the work of Quine with that of Russell.

Russell's commitment in striving against the idealist outlook was certainly a momentous landmark in the inauguration of analytic philosophy (Akehurst 2010). The idealists overly privileged the operational status of the mind, whereby the mind bore a direct influence in correlating or coordinating external objects of reality. This meant that our conception of reality in the manner which we understand it is a reflection of the processes that occur in our minds. Consequently, for the idealist, ideas (which are constructs of the mind) stand as the true objects of knowledge:

[Idealism] claims that the external world can be grasped only by reference to the work of ideas and that all we can say about the external world is mediated by operations of the mind. The world in itself is certainly mind-independent, but the world as conceived by us must be constructed by mind. (Bunnin and Yu 2004, 323)

This evidently infers an a priori approach to the acquisition of knowledge of the external world. Russell, along with G.E. Moore, took issue with this approach. ${ }^{20}$ For Russell, the idealist approach to knowledge failed to bear the objectivity and preciseness it ought to have had. The lack of epistemic objectivity and precision resulted in a kind of deprivation of the power of the mind, namely, of the ability to know things.

The faculty of being acquainted with things other than itself is the main characteristic of a mind. Acquaintance with objects essentially consists in a relation between the mind and something other than the mind; it is this that constitutes the mind's power of knowing things. (Russell 2008, 30)

As a result, Russell postulated an epistemic stance which inferred a direct and immediate association between the mind and the external world. It was an association which closed the intermediary gap ${ }^{21}$ between 
the subject and object in coming to know something. This sort of knowing was termed 'knowledge by acquaintance' as opposed to 'knowledge by description. ${ }^{22}$ Knowledge by acquaintance purported an omission of any intermediaries between being immediately conscious of the external world and the external world itself. ${ }^{23}$ This bestowed the mind with a privileged status whereby it was in direct contact with a world external to it. Moreover, this direct contact provided for a sense of objectivity between the mind and the external world-one which averted the issue of idealism and left little room for error. ${ }^{24}$

But what of those things which we possess knowledge of, yet they don't seem to be objects of acquaintance (for example, abstract ideas)? In response to this, Russell adamantly maintained that

We should only know what is now present to our senses: we could not know anything about the past-not even that there was a past-nor could we know any truths about our sense-data, for all knowledge of truths, as we shall show, demands acquaintance with things which are of an essentially different character from sense-data, ${ }^{25}$ the things which are sometimes called 'abstract ideas', but which we shall call 'universals'. (Russell 2008, 34)

All such kinds of knowledge which we possess while lacking objects of acquaintance must, for Russell, eventually be reducible to things that exist. It is evident that for Russell there is an essential connection between the things that exist and the immediate apprehension of those things by way of acquaintance. ${ }^{26}$ This lucidly explains his 'principle ${ }^{27}$ : "Every proposition which we can understand must be composed wholly of constituents with which we are acquainted" (Russell 2008, 40). Thus, if a proposition is composed of, or includes, things with which we are not acquainted, then it would probably infer one of two things. In the first instance, the proposition's violation of this principle would eventually accord with it, since all abstract entities (which Russell preferred to call 'universals') are reducible to things that exist and subsequently that we know by way of acquaintance (or description). In the second instance, if such entities insistently fail in being reduced to things that exist and subsequently we cannot know by way of acquaintance (or description), then they would ultimately fail to possess meaning. ${ }^{28}$

Alternatively, Russell's principle may be observed as featuring two salient aspects. The first is that knowledge by acquaintance is independent of those beliefs, concepts, and propositions that resist being reduced to things 
that exist. The second is that under the correct circumstances that allow (and subsequently demonstrate) such beliefs, concepts, and propositions to be reduced to things or objects that do exist, the association would not be between these beliefs, concepts, and propositions and their subject. Instead, the association would then be between the subject and the object that subsists (i.e. the referent).

Quine, however, opposed this view. His dismissal of Russell's position took place in the course of proposing an alternative outlook to the same kinds of epistemic questions. Quine sought to provide a naturalist explanation in responding to fundamental questions such as, how do we come to acquire the knowledge that we possess? Or, what is the relation between our mind and the external/physical world? Given Quine's scholarly commitment towards a worldview which was almost completely driven by science, his naturalistic approach to such fundamental questions of epistemology is unsurprising. ${ }^{29}$ In fact, Quine opens one of his papers, aptly entitled "Epistemology Naturalized," with a predictable yet stark claim: "Epistemology is concerned with the foundations of science" (Quine 1969, 69). To put it crudely, the manner in which 'epistemology is concerned with the foundations of science' is by way of substantiation. This is to say that the foundations upon which science operates and prospers, namely causality and induction, must prove to be "verifiably adequate" 30 in erecting the edifice of our knowledge. Of course, this cannot evade the fact that the scientific (theoretical) accounts which are offered in attempting to discern between our perception and the physical world are themselves grounded in causal stimulation that trigger our perceptions in a certain way. This would entail a blatant form of circularity, since to rest the edifice of knowledge on the foundations of science would mean to rest it on principles such as causality and induction. Moreover, to obtain the least possible understanding of causality and induction would mean being able to perceive such phenomena. However, perception is triggered by an extensive variation of stimuli that we anticipate theorizing about in the name of science. In essence, this is to say that our knowledge is best substantiated on the back of science which is itself (retrospectively) substantiated on our perceptionary knowledge.

Astoundingly enough, this circularity was not acknowledged. ${ }^{31}$ Instead, science was revered as offering the best possible framework upon which to build a theory of knowledge. This meant that the methodological framework upon which science gained its prominence was not rigorously contested, resulting in a kind of intellectual complacency which hardly felt the need to explore alternative methods. Science, for naturalists like 
Quine, was espoused as the substratum upon which our understanding of fundamental questions of epistemology are founded. Questions like the ones alluded to above (how do we come to acquire the knowledge that we have? Or, what is the relation between our mind and the external/physical world?) would thus be observed as 'scientific' questions. Consequently, such questions fittingly deserved to be answered with motifs that were scientifically driven. For Quine, responding in this way to such fundamental questions meant offering our representations (as responses) to the effects that the world has upon us. Such representation would be in virtue of

Various forms of energy, most obviously light, sound, and heat, impinge on the surfaces of our body; in some cases, a person responds differentially to such impingements. Thus we may respond in one way when a certain pattern of light is impinging on our eyes and in another way when it is not. The body contains sensory surfaces that are stimulated by impingement of the relevant forms of energy; these stimulations affect behavior. (Hylton 2004, 117)

This may appear to be a scientifically reasonable account of how a naturalist as the likes of Quine may go about responding to the above questions. Nonetheless, such an account doesn't close the gap between how various forms of energy impose on the exterior of our bodies and stimulates (by way of impingement) our behaviour and our thoughts about the world. More importantly, if these various forms of energies that influence our behaviour (stimulation) are to maintain a status that substantiates science, they would have to be free from subjectivity. In other words, if we are to accept that these various forms of energy amount to our observations, namely the kind of "observation which affords the sensory evidence for scientific theory" (Quine in Johnsen 2014, 333), then such science would be founded on internal/private considerations. It would, in essence, be establishing science on internal/private thoughts that fail to draw on any common ground from where others can deduce. ${ }^{32}$ This clearly presented a fundamental problem for Quine, one which he himself was well aware of. ${ }^{33}$

For Quine, the solution to this dilemma lay in what he called 'observation sentences'. These, loosely put, were conveyances of our observations in the form of language. Such conveyances were distillations (as Quine put it) of our observations. They did away with things that failed to represent observations, such as 'sensations' or 'environing situation'. As a result of this, observation sentences were linguistic expressions that reported observations. More importantly, observation sentences reported observations on a 
communal level. This meant that their utterances would induce a consensus among those who were equally subjected to the same set of impingements as the utterer. ${ }^{34}$ Furthermore, instances that were observed and represented by observational sentences were those that could be empirically verified. ${ }^{35}$ This meant that the observation sentences that were uttered in representing those observed instances would be accepted by anyone else who was witnessing (or experiencing) the same instances by way of impingement of energy upon their surface receptors. Consequently, observation sentences would avoid internal/private considerations, allowing us to state the impingements of energy on our sensory surfaces by way of observation. This, in essence, is what would amount to a scientifically established fact for Quine: one that yields a formidable groundwork upon which the edifice of our knowledge can be confidently erected. ${ }^{36}$

By now it may be evident that Quine's outlook on how an association is to be made between our thoughts/words and the external world fared differently from that of Russell. Russell offered his approach in making such an association and coming to know something on the basis of 'acquaintance. Quine, on the other hand, prioritized a naturalistic approach that was ultimately based on observational sentences. The noteworthy distinction between Quine and Russell (pertaining to how our utterances come to represent the world in the manner in which we know it) has to do with reference. For Russell, reference sits at the heart of associating our thoughts and utterances with the world. It is what binds our considerations and language with the external world in a manner that offers a form of objectivity. In contrast, Quine offered a position that was relational and less referential. This meant that the association between our considerations and language was to be found in a relation between observational sentences and how those sentences fared in view of those who were subjected to equal stimulations of the energies that impinged upon them. ${ }^{37}$ This is not to imply that, for Quine, reference is a vacuous concept which fails to bear any relevance between us and the world. ${ }^{38}$ Even though he does not consider reference to be fundamental, he nonetheless concedes that it has a role in obtaining some form of conceptual clarification which extends to our language. ${ }^{39}$

Demoting the functionality of reference, whereby it does not serve as a fundamental relation between our utterances and the world, grants observational sentences this fundamental role instead. Now, if observational sentences operate to determine the truth-value of any given sentence, then this would imply that the truth-value of those sentences have been determined prior to any function of reference. In other words, 
The fact that reference is, in the sense we have discussed, not fundamental shows itself in the fact that we must begin with a set of true sentences, a body of theory that is true, or at any rate accepted as true. Only when the truths are in place can we raise the question of existence. In this sense, acceptance of sentences is prior to reference, and truth is prior to existence. Those objects that a given body of theory is about are presumably the ones that must exist if that body of theory is to be true. They are, in Quine's words, the ontological commitment of that body of theory. (Hylton 2004, 122)

The truth-value of our utterances concerning an object in the external world, in this sense, would precede any talk of its existence. If the manner in which the truth-value of any given object that is situated in the external world is determined to be true by way of observational sentences, then it would consequently imply that that very object must evidently exist. Otherwise it would not have been the subject of truth or falsehood from the outset. This situates the determining of truths by way of observational sentences before we can engage in any ontological pursuit of the very object that is the subject of observational sentences. Moreover, this reveals the intimate theoretical connection between Quine's philosophy of language and his ontology, whereby the former precedes the latter.

\section{2: Quine's Ontology}

This is the juncture where we make our transition between Quine's philosophy of language and his ontology. The source of this transition seems to reside in what Quine terms 'ontological commitment', that is, the conviction one ought to uphold pertaining to the types of objects/entities manifested in or as a given sentence-a sentence that has been accepted as true. It thus functions as a conceptual mediator in reaching some form of existential certitude about particular objects/entities expressed in language. One way to acknowledge the bridge between this ontological notion and observational sentences is as follows: suppose we assert the open sentence ${ }^{40}$ "There are short giraffes." This would ontologically commit us to the existence of at least one 'short giraffe' in virtue of its truth already being determined by an observational sentence. This is to say that we are only obliged in assenting to the ontological commitment of a 'short giraffe' in this case, which is expressed in or as a statement, only once it has been accepted as being true. This truth, as we have discussed, is based on observational sentences. The 
sequence in determining the truth prior to its existence in this example reemphasizes Quine's view of truth preceding existence.

Therefore, this approach proposes that if a propositional statement that is about any specific object/entity is considered to be true, it would entail that that object/entity must exist. ${ }^{41}$ For Quine, the manner in which this idea is to be presented, so that it bears a degree of precision in the sorts of things we become ontologically committed to, is first-order predicate logic. First-order predicate logic, with the aids of existential and universal quantifiers, manages to differentiate between the exact kinds of objects/ entities (stated in a sentence) that we would be existentially committed to and those we would not be committed to. Allow me to demonstrate this. As before, suppose we accept the following sentence as being true:

There are short giraffes.

Now, in order to determine our ontological commitment to the objects/ entities mentioned in this sentence, we would require 'regimenting' the sentence in the notation of first order predicate logic. Having done so, it would be expressed as follows:

$\exists \mathrm{x}(\mathrm{Gx} \wedge \mathrm{Sx})$

Given that we are aware of the domain of our quantification, this would read as follows: 'there exists (or there is) at least one $\mathrm{x}$ such that $\mathrm{x}$ is a giraffe and $\mathrm{x}$ is short'. There are two symbolic components used in this sentence that are to be noted. The first is the use of the existential quantifier ' $\exists$ ' and the second is the variable ' $x$ '. When both of these symbols are used to represent a statement, it epitomizes the existence of that particular thing whose name has been replaced by the variable ' $x$ '. Moreover, for a name that is replaced by a variable ( $\mathrm{x}, \mathrm{y}, \mathrm{z}$, etc.) to express a complete thought, it must be bound within the scope of a quantifier. If a variable fails to be bound by a quantifier it shall equally fail to express a complete thought which bears any clear meaning. Upon having successfully symbolized the sentence that we have taken to be true in first-order predicate logic, we would subsequently commit to those entities that represent the values of the bound variable(s). This means that in virtue of the sentence, 'There are short giraffes', we would be committed to the existence of at least one entity expressed by the bound variable, which in this case is a 'short giraffe'. Our ontological commitment in the case of this statement then is situated among the value of its bound variable, given that we accept this statement to be true. This 
is neatly summed this up in a famous slogan, "To be is to be the value of a bound variable".

One way to appreciate the comprehensiveness of this particular slogan would be to acknowledge it as a response to a fundamental question in ontology, namely, 'what is there?' In fact, for Quine, the term 'ontology' is tantamount to this very fundamental and inescapable question that almost acts as an antecedent of the discipline. Quine's approach to this ontological question draws upon conceptual perspectives in order to determine (as definitively as possible) the kinds of things (objects/entities) we should ontologically commit to.

Alternatively, we may appreciate this slogan by way of analyzing the ontological components that it is comprised of. This yields a succinct overview of Quine's ontological framework (or meta-ontology, rather) by way of presenting the specific views that constitute his ontology. In this respect, I refer to the work of Peter Van Inwagen $(1998,2014)$, who condenses Quine's ontology into five theses. Four of these five are sufficient for purposes of our argument; I offer a brief synopsis of each of these here, and apply them to a few selected examples. Subsequently, I shall demonstrate how each of these theses proves to be a prerequisite of the two readings of metaphysical (theological) realism.

The following propositional statements summed up by Van Inwagen meticulously account for Quine's ontological commitment and quantification:

Thesis 1 : Being is not an activity

Thesis 2: Being is the same as existence

Thesis 3: Being/Existence is univocal

Thesis 4: The single sense of being or existence is adequately captured by the existential quantifier of formal logic

Thesis 1: Being is not an activity

If it were inquired, what it was that someone did at a given moment in time when they were doing 'nothing' (not the kind of 'nothing' that is meant in an absolute sense), we may intuitively respond by saying that they are living, breathing, thinking, emitting heat, standing, sitting, lying down, etc. In this case we attempt to seek the most generic and perpetual activity simpliciter that the person in question may be engaged in. This would more than likely include a range of involuntary actions that manage to reveal the most basic form of activity directly associated with its subject. However, would 
such an activity (or activities) succeed in portraying the most basic thing one cannot possibly be free of if they are to subsist? At this stage we may be inclined to infer that the subject's being (or existence) is perhaps the most generic activity. In this sense we would consider the subject's being (existing) as the most basic activity one might engage in. Moreover, being would also be conceived of as the most fundamental component in allowing the subject to be what it is (to subsist as whatever it is).

Both these responses (namely, the range of involuntary actions and being or existence itself) would be considered as 'activities'. This, according to Quine, is fallacious, since being cannot be thought of as an activity of any sort. Whatever it is that we consider the most generic activity to be, associated with the subject in question, it must be one that is able to enact such an activity, presuming there is something. In other words, unless one is or subsists, we cannot attribute any activity to that subject, let alone any talk of the most generic of activities. Given this, the 'is', or more aptly the 'being', of the subject in question cannot also be considered as an activity itself if it is to sustain an activity.

Thesis 2: Being is the same as existence

Suppose I affirm the following claim: "I believe in many things that do not exist, such as mermaids." This would ostensibly be representing a cognitive mental state ${ }^{42}$ that I happen to sustain. Moreover, it would be making a distinction between 'what (I believe) there is' and 'its existence'. Aside from the truthfulness of the claim, it appears to categorize the being of something and its existence as two distinct realities that can both hold to be the case. For Quine, however, this would not only appear contradictory in what is being affirmed but also delusional. The reason for this is quite simple. Quine did not see any reason for why anyone should distinguish between a thing's being and its existence. Both terms denote one and the same reality. This means to say that you cannot in any sense of the matter have a thing that is yet it does not exist. Whatever is, exists; whatever is not, does not exist. Therefore, since you cannot have things that do not exist, my claim regarding mermaids cannot be any more erroneous according to Quine. This is because I am affirming (by upholding a belief) that there are mermaids while concurrently affirming the negation of their existence. As a result, I am mistakenly inferring a distinction between the being of a mermaid (which I happen to believe) and its existence. 
Thesis 3: Being/Existence is univocal

This follows from the preceding thesis (2). Its succession can be appreciated as a transition from an ontological perspective to a semantic perspective pertaining to being and existence. In the former thesis (2), we acknowledged that being and existence are the same from an ontological viewpoint. Subsequently, in this thesis (3) it is professed that we should acknowledge, accordingly, that being and existence denote the same thing from a semantic viewpoint. This means to assert that, given that the terms 'being' and 'exist' refer to one and the same thing (ontologically), it would follow that both terms only have one possible meaning irrespective of the things that they are applied to. Those philosophers who think that terms such as 'there is' and 'exists' bear differing connotations depending on the entities they are applied to (material, mental, or abstract) are deeply mistaken. According to Quine, although it may appear an attractive position, this is both a denial of the previous thesis (2) and also simply false.

To be able to appreciate this position, let us draw on another example. Let us take the following two statements to be true, namely, "there are short giraffes" and "mermaids exist". Moreover, let us categorize the subjects of each of these propositional statements in the following groups, namely, material (or tangible) and mental (or mythical). Now, if both of these statements are taken to be true in what they denote (ontologically and from a semantic perspective), it would infer that the terms 'there are' and 'exists' are not the same ontologically (repudiating thesis 2 ). In other words, the referent of the two terms and their existence are two distinct realities that can both be upheld to be the case. Secondly, this would imply that the terms 'there are' means one thing when applied to short giraffes while 'exist' means another thing when applied to mermaids. In other words, the two terms are thought to denote different meanings when applied to material/tangible and mental/mythical entities. Both of these consequences, according to Quine, would be incorrect. He aligns the univocal nature of existence with the univocal nature of arithmetic. Most people would agree that the application of arithmetic is to primarily determine the quantitative value of whatever is in question. Numbers in this sense can be applied to any entity in order to determine its quantitative value. For instance, let us take the following two statements to be true: "I fed 2 short giraffes" and "I saw 2 mermaids". The numbers in each of these statements inform us of the quantitative value of each of the stated entities (the subjects). There are two different entities that are being referred to in both of these statements. The 
short giraffe may be categorized as a material entity, while the mermaid can be categorized as a mental entity. Despite the application of the numbers to differing entities, the numerical value is identical-which is to say that the number of short giraffes is the number of mermaids. It is evident that just because we may apply the same number to differing entities this does not alter their quantitative value. This demonstrates that numbers bear a univocal nature (the number denotes the same value regardless of the entity to which it is applied). This is how existence should be conceived of, by this account. Whatever term is used to denote the existence of any entity, it must bear a univocal nature like that of numbers.

Now, if numbers and existence should be conceived of as bearing a close association, statements like the ones above should then inform us of something more than the quantitative value of entities. According to Quine, they do. Both of these statements inform us of the ontological status of each of these things being enumerated. This means to say that since both of these statements are considered to be true, we can safely interpret them as synonymous to: "there are/exist 2 short giraffes that I fed" and "there are/ exist 2 mermaids that I saw." If, on the other hand, short giraffes and mermaids did not exist, then I would appropriately say, "I fed 0 short giraffes" and "I saw 0 mermaids." This would be interpreted as "there is/exists 0 short giraffes that I fed" and "there is/exists 0 mermaids that I saw."

This demonstrates that while numbers determine the quantitative value of the entities that they are applied to, the resulting quantification presupposes its ontological status (namely, whether it exists). This would suggest that entities which fail to possess any credible ontological status would be associated with the number 0 , while anything that does possess an ontological status would, in the least case, be 1 or greater than 1 . Thus, if I were to say that "mermaids do not exist" it would be similar to, if not the same as, saying that "the number of mermaids is 0"; if I were to say, "there are short giraffes," it would be similar to, if not the same as, saying that "the number of short giraffes is 1 or more".

Let us now revisit the former example in light of what has followed. The two statements presented earlier were "there are short giraffes" and "mermaids exist" - both of which considered to be true. Within both of these examples are two different predicate terms being used for two different entities; the terms "there are" is used for short giraffes while "exist" is used for mermaids. Just because we use two different predicate terms for two different entities does not imply that they both begin to possess an ontological status which manifests their existence (making both of them 
true). Being and existence should, according to this thesis, be univocal, just like numbers. Therefore, just as if the number ' 2 ' was affixed preceding 'short giraffes' and 'mermaids' would not alter the quantitative value and would remain univocal (regardless of the two differing entities it is applied to). This should equally be the case with predicate terms such as "there are" and "exists". Using the latter term after mermaids would not approve of the actual existence of mermaids, since mermaids are mythical creatures.

Thesis 4: The single sense of being or existence is adequately captured by the existential quantifier of formal logic

Although I have elaborated on the existential quantifier in the above section it is worth noting a supplementary point. In our previous example I presented the statement "there are short giraffes", which we accepted as true. Subsequently, this was regimented in first order predicate logic that was expressed in the following manner:

$\exists \mathrm{x}(\mathrm{Gx} \wedge \mathrm{Sx})$

We then stated that this statement can be read back into ordinary language in a more precise mode, namely: 'there exists (or there is) at least one $\mathrm{x}$ such that $\mathrm{x}$ is a giraffe and $\mathrm{x}$ is short. This infers that the existential quantifier captures the truth and ontological status of at least one of the entity it quantifies. Therefore, "there is at least one short giraffe" would be equivalent to "at least one short giraffe exists."

\section{3: Quine's Ontological Theses and Metaphysical (Theological) Realism}

I shall now proceed to demonstrating how Quine's theses (which constitute his ontological outlook) prove to be a prerequisite of metaphysical (theological) realism. This would include making reference to the two possible readings of metaphysical realism (see Ahsan 2017) and how Quine's theses presuppose them in different ways.

Earlier I stated that metaphysical (theological) realism can be construed and read in at least two possible ways:

Reading 1: God is included in this mind-independent reality.

Reading 2: God is identical with this mind-independent reality.

The theological implications which each of these possible readings bear have already been mentioned. My task here is to determine that each of Quine's ontological theses are prerequisites of the two readings of meta- 
physical realism. I shall manifest how each of Quine's ontological theses stands as an underlying cause from which any one or both of the readings of metaphysical (theological) realism can be inferred. This is not to imply that there exists mere consistency between the two, but rather that Quine's ontological theses act as preconditions for the two readings of metaphysical realism. That is, metaphysical (theological) realism is true only if Quine's ontological theses are true. Additionally, if these conditions set by Quine's ontological theses were not met by metaphysical (theological) realism, then both readings would fail to uphold their inferences in the manner they do.

\section{Thesis 1: Being is not an activity}

This particular thesis would ostensibly bear no connection to any one of the two readings of metaphysical (theological) realism. Affirming it would in fact yield the fundamental being of any one of the two readings. This can be appreciated if we were to assume that God's being is an activity. In such a case, according to the phenomenologists, ${ }^{43}$ God would fail to bear any existence at all-there would be no God. This is because if God's being were to be considered an activity of the most general sort (or even something different from what we as humans beings would consider to be the most general activity simpliciter), then such an activity would make God devoid of immutability, since He would have been fundamentally dependent upon the most general activity in order to subsist.

In addition to this, and perhaps at a meta-ontological level, if we assent to this thesis on the grounds mentioned, then it would have to be an assent which supersedes both of the metaphysical-theological readings outlined. Allow me to demonstrate this. Suppose that we were to merely consider accepting either one of the two proposed readings, namely, God is included in this mind-independent reality or God is identical with this mind-independent reality. Prior to having accumulated enough reasons to be convinced by one of them over the other, the mere consideration of possibly accepting any one would infer something common in both of them. This would primarily be that God is (as in, He exists). This would, at least momentarily, overlook whether $\mathrm{He}$ is included in or identical with a mind-independent reality, and take for granted perhaps that $\mathrm{He}$ is. More importantly, we would also agree that our mere consideration towards the two readings presupposes that for Him to be identical or included in this mind-independent reality $\mathrm{He}$ would primarily have to $b e$. Of course, for any given subject to be included in anything or identical to anything, it has 
to first be-otherwise, in the absence of a subject, the predicates 'included' and 'identical' would fail to possess any meaning.

All of this appears to be in line with a theological account of matters pertaining to metaphysical realism. However, the issues only become apparent when it is acknowledged that this thesis has a considerable overlap with its proceeding ones. For instance, aside from considering this fundamental being (and the is of God) to be one that is independent of any association with a verb and activity, Quine further holds that this very fundamental being (and the is of God) bears no difference from the fundamental being of you, me, a table, a tree and every other materialistic thing that constitutes our reality. The only way we differentiate between these things is by way of our natures and not by way of our beings. This is where the theological problem begins to manifest. The proceeding thesis shall serve to be more relevant in revealing these issues and in making the connection between them and the two readings of metaphysical (theological) realism.

Thesis 2: Being is the same as existence

This thesis bears a connection with reading 1 . That is to say, it would act as a source or a cause from which we would be able to infer that God is included in this mind-independent reality. In order to appreciate this connection, let us take being to be the same as existence as endorsed by this thesis. If in this sense I am to affirm that "I believe that there is a God," it would be equivalent to saying "I believe that God exists" or "I believe that there is such a thing as God." This, rather plainly, means that if God is, He exists; and if $\mathrm{He}$ were not, He would not exist. Although God may be categorized as a separate entity (only by way of our natures) from things like you, me, a table, chair, or tree, His being would be the same as anything else's existence. Any attempt at drawing a distinction between God's being and another entity's existence would, according to Quine, be unacceptable in duplicating realities. ${ }^{44}$ Consequently, God cannot be a completely separate entity (by way of our beings) that we may go on to distinguish using the terms 'being' and 'existence.' That is to say, if God exists then His ontological status cannot be distinguished from any other entity that also exists; both their being and existence would suppose a subsistence that is occupied by a single reality. On this view, if God is to be distinguished from anything else that exists, than it will be in virtue of their natures and not their beings.

This conception of God situates Him on an ontological par with everything else that exists. Moreover, it insists that any attempt to distinguish His ontological status from anything else that exists would be fallacious. This is 
what reading 1 of metaphysical realism also infers. It supposes that God is included in a mind-independent reality. His inclusion in this reality equally infers that $\mathrm{He}$ is on an ontological par with everything else that exists in this single reality. If it is to be/exist, then, accordingly, it is to be inhibited within the confines of this one single reality.

Thesis 3: Being/Existence is univocal

This thesis further bears a connection with reading 2 and also 1. It acts as a source or a cause from which we would be able to infer that God is, identical with and also included in, this mind-independent reality. In order to appreciate this connection, let us begin by taking being/existence as univocal, as is endorsed by this thesis (3). Again, let me affirm the claim that "I believe that there is a God", or equally if I say "I believe that God exists" or "I believe that there is such a thing as God". According to this thesis, my affirmation implies that being and existence denote the same thing from a semantic viewpoint. This thesis follows on from thesis (2), in which no ontological distinction should be made between God's being and His existence. In other words, if we concede to thesis (2) and make no distinction between God's ontological status and everything else that exists, then the terms we use to denote His being or existence must mean the same kind of existence and being as everything else. If we were to apply certain terms to God with the thought that these terms bear special connotations in virtue of the divine entities they are applied to, it would be incorrect.

Let us refer to Quine's way of demonstrating this thesis by aligning the univocal nature of existence with the univocal nature of arithmetic. In this sense, my claim, "I believe that there is a God" (or "I believe that God exists" or "I believe that there is such a thing as God") would mean that "I believe that there is at least one God that exists." The number 'one' applied to God in this sense would determine (and quantify) His ontological status, given the association between existence and numbers according to Quine. The usage of the number 'one' in this sense should be equivalent to its usage for any other entity that I make a similar claim about. Again, if I were to claim that "I believe that I witnessed a short giraffe", it would mean to say that "I believe that I witnessed at least one short giraffe that exists". The usage of the number 'one' would equally determine the ontological status of the short giraffe (a material being) and of God (a supernatural being) in the previous claim. For Quine, again, the univocal nature of numbers ought to be the manner in which we think of the univocal nature of being and existence. 
This understanding appears to entail a univocity in the manner we are to perceive God if we are to accept His existence. This univocity would, as demonstrated, resemble that of numbers. More importantly, however, the univocity offered by this thesis (3) not only presupposes the affirmation of the preceding thesis (2) but distinguishes between the ontological status itself and the terms used to denote that ontological status. Thesis (3) then appears to build on thesis (2). If we are to affirm this thesis (3) and its implications on the grounds that we affirm the preceding thesis (2), then it would imply that God's being is ontologically analogous to the being and existence of everything else that subsists in a singular reality and that the terms we use to denote His being or existence must be univocal. Nonetheless, if both theses work in collaboration, how are we to specify the metaphysical (theological) reading it would be the source (or cause) of? The previous thesis (2) was associated with reading 1 of metaphysical (theological) realism, while this thesis (3) presupposes its preceding thesis (2). This would beg a further question: can thesis (3) be applied independently of thesis (2)? I think not-at least, not in any meaningful way. If thesis (3) were affirmed independently of thesis (2), it would be prescribing in isolation that we ought to ensure that the terms we use to denote the being or existence of different entities mean the same thing. If this claim is made while denying thesis (2), which is to say that it upholds being and existence as two ontologically different realities, then its claim (thesis 3 ) would be vacuous. It would be absurd to affirm the usage of terms like being and existence as univocal while simultaneously upholding that this is not ontologically the case. This would sever the correspondence between our language and its referents, leaving mere words to account for something that is denied to be the case.

Therefore, this thesis (3) - while affirming the preceding thesis (2)would be the source (and cause) of reading 1 and 2 of metaphysical (theological) realism. I have already shown how thesis (2) would be the source of reading 1 , which is inclusive of this thesis (3). The way in which this thesis (3) would be the source of reading 2 is as follows. Let us refer to my previous claim that "I believe that there is a God". This would primarily have to comply with thesis (2), since thesis (3) presupposes it. Subsequently, assenting to thesis (3) would mean ensuring that the terms I use to denote God's being or existence are univocal. Conforming to both of theses ( 2 and 3 ) in association with one another would mean that (a) I accept that God's being is ontologically the same as anything else that exists and (b) the terms I use, such as His 'being' or 'existence', are univocal. Moreover, the way in 
which we understand the univocal nature of terms such as 'being' and 'existence' is equivalent to that of numbers (as we have discussed). This view suggests that the way in which the quantitative value of numbers would remain equal, regardless of the entities you apply them to, ought to be the same when applying terms like 'being' and existence' to different entities. This attributes (abstract) numerical quantification to the univocal nature of existence. It specifies being and existence with a particular numerical value.

In line with this view, my claim "I believe that there is a God" would be construed as "I believe that there is at least one God that exists". The number 'one' would denote at least two things in this instant. Primarily, it would infer that there is one God from a quantitative perspective. Secondly, it would infer that there is at least one God that exists from an ontological perspective. Both the numbers 'one' used to demonstrate the connotations referred to in each of the perspectives would be univocal in what they connote and thus support Quine's view pertaining to numbers being closely associated with existence. Now suppose I made a subsequent claim, such as "I believe there is a reality"; again, this claim would be construed as "I believe that there is at least one reality that exists". Moreover, the number 'one' here would also denote at least two things. First, it would infer that there is one reality from a quantitative perspective. Second, it would infer that there is at least one reality that exists from an ontological perspective. Once more, both the numbers 'one' used to demonstrate the connotations referred to in each of the perspectives would be univocal in what they connote.

In this respect, when we review both of my claims it would infer that the number 'one' in my God example (A) would have to be univocal on both accounts of what it connotes to the number 'one' in my reality example (B).

\begin{tabular}{|l|l|l|}
\hline & Example A & Example B \\
\hline My original claim & $\begin{array}{l}\text { I believe that there is a } \\
\text { God }\end{array}$ & $\begin{array}{l}\text { I believe that there is a real- } \\
\text { ity }\end{array}$ \\
\hline Construed as & $\begin{array}{l}\text { I believe that there is at } \\
\text { least one God that exists }\end{array}$ & $\begin{array}{l}\text { I believe that there is at least } \\
\text { one reality that exists }\end{array}$ \\
\hline $\begin{array}{l}\text { Quantitative connota- } \\
\text { tion }\end{array}$ & there is one God & there is one reality \\
\hline $\begin{array}{l}\text { Ontological connota- } \\
\text { tion }\end{array}$ & $\begin{array}{l}\text { there is at least one God } \\
\text { that exists }\end{array}$ & $\begin{array}{l}\text { there is at least one reality } \\
\text { that exists }\end{array}$ \\
\hline $\begin{array}{l}\text { Nature of the numeri- } \\
\text { cal figure used }\end{array}$ & $\begin{array}{l}\text { The number 'one' used in both of these examples would } \\
\text { have to be univocal. }\end{array}$ \\
\hline
\end{tabular}


As a result, the predicate of each of the subjects in both examples would have to mean the same (as in they would imply being identical), which in essence is to say that the subject would be what the predicate is telling us about it. In example (A), we are told that there is one God; in example (B), we told that there is one reality. In both instances, if the oneness (the predicate) is being shared to mean the same thing by both subjects (where God is understood to be one and reality is also understood to be one), it would suggest that the predicates and the subjects are identical to one another. However, this would be a rather unconventional approach in the philosophy of language. To interpret 'is' as indicating identity and not predication would, for most philosophers of language, be a glaring fallacy that is too obvious to overlook. If I were to use 'is' in this manner and say that 'Muhammad Ali is strong', then it would make him identical to his strength. If I subsequently went on to say that 'Joe Frazier is strong', again using 'is' in the same manner, it would make him identical to his strength. Consequently, if $\mathrm{a}=\mathrm{b}$ (where ' $=$ ' is interpreted as numerical identity and not qualitative identity), $b=a$, and $b=c$, then $a=c$ : this equation would unequivocally imply that Muhammad Ali and Joe Frazier are the same person.

My reason for adopting such an approach, which would be considered fallacious according to most philosophers of language, is because I view it from a metaphysical perspective. Metaphysicians typically distinguish between 'numerical identity' and 'identity in the strict sense' (qualitative identity). In metaphysics, then, when you have a claim that makes a connection in virtue of identity between two objects/entities, such as $a=b$, it implies that 'a' and ' $b$ ' are numerically identical. This means that despite being two distinct symbols ( $\mathrm{a}$ and $\mathrm{b}$ ) they are numerically one. This is because the notion of identity is being conceived as numerically univocal and thus taken to mean one from a quantitative perspective. On the other hand, the more conventional manner of conceiving identity, is qualitative identity. In this sense when we hear people claiming that "these two bicycles are identical" what they usually mean is that both of these bicycles possess identical features which probably make it difficult to distinguish between them. However, they don't mean to say that both these bicycles are one of the same thing, in a numerical sense. According to metaphysicians, then, qualitative identity lacks a genuine sense of manifesting identity.

My reason for elaborating this metaphysical perspective is because it appears to correspond with Quine's prescribed view in this particular thesis (3). Since Quine postulates that being and existence are univocal, and 
demonstrates this by way of association to numbers, it aligns with this view of numerical identity.

This is what reading 2 of metaphysical (theological) realism also infers. It proposes that God is identical with a mind-independent reality, much like the two examples that have been presented. The subjects of both my claims, namely, God and reality, would fundamentally share an ontological nature and have terms used to denote this singular nature that are univocal. Therefore, it would be equivalent to saying that God is identical with this reality (resulting in a form of pantheistic belief).

Thesis 4: The single sense of being or existence is adequately captured by the existential quantifier of formal logic

This thesis also bears a connection with readings 1 and 2 of metaphysical (theological) realism. However, the way in which it does so is different from thesis (3). Thesis (4) can be seen as a more generic way of depicting all its preceding theses. In order to appreciate this, let us take my claim once more, "I believe that there is a God". Let us regiment this claim so that it is depicted in the form of first-order predicate logic.

$\exists \mathrm{x}(\mathrm{Gx})$

This statement can be interpreted back into ordinary language (with a few modifications in order to ensure precision) as follows: 'I believe that there exists (or that there is) at least one $\mathrm{x}$ such that $\mathrm{x}$ is God.' Once the claim has been regimented in the notation of first-order predicate logic, we would be committed to the existence of the particular entity that is represented by the bound variable, in this case 'God'. This would be the manifestation of my ontological commitment.

Given this, whatever it is that I am ontologically committed to, it must be an entity that conforms to the preceding theses. Otherwise my ontological commitment would serve to be quantified by the existential quantifier in a manner that either disregards what the ontological quantifier actually stands in place for, or it would be one that is vacuous of any real ontological status in the way Quine has prescribed. Therefore, the ontological quantifier can be seen as a depictive symbol that exercises a kind of ontological understanding of the type that we have been discussing (with respect to the previous theses).

On this view, we can take this thesis (4) as one that is comprised of the preceding theses. It thus has the potential of being a source or a cause from which we are able to infer both readings of metaphysical (theological) 
realism. Once the existential quantifier is unpacked in virtue of its presupposed theses, the way in which each of them would infer either or both of the readings of metaphysical (theological) realism is something that I have attempted to cover in this paper.

However, if the existential quantifier is a depiction in symbolic form of Quine's ontological outlook as a whole, how would it receive my claim, namely, "I believe that there is a God"? What I mean by this is-despite the existential quantifier being comprised of the preceding theses-in virtue of what would my claim be considered as being the case (true) prior to determining its ontological status? This question is fundamental, since for Quine truth precedes existence. If my claim fails to bear a truth-value then it would not bear any existential value that can be adequately captured by the bound variable. This would imply that the existential quantifier would fail to espouse any meaningful import.

In Quine's view, the truth of statements (or entities/objects within statements) is determined by way of observational sentences. These are linguistic formulations of the observations we make via our preceptionary receptors. These observations avert private/internal interpretations of the observations we experience by making reference to observations on a communal level. This, according to Quine, meant that the experiences a single person undergoes pertaining to the impingements of energy on their surface receptors would have to be ones that are equally experienced by others who undergo the same impingements. This would result in common observational sentences when the same thing is perceived by different perceivers. Given these general parameters, would the God which I have used in my examples qualify as being experienced on a communal level by way of the same impingements of energy that each of us may perceive? I believe not. This approach is a naturalistic method of determining the truth and existence of an entity/object. It is difficult (perhaps near impossible) for this method to allow supernatural entities/beings to bear any truth-value-and, subsequently, any existence at all. In fact, this reveals that Quine's naturalistic attitude, which influences his philosophy of language and shapes much of his ontological outlook, lies at the core of the issue. It is this broad naturalism that refuses to confer any meaningful and true import to entities/ beings in theological matters that transcend human cognition. The same holds true of metaphysical realism more broadly, as it relies upon Quine's ontology. 


\section{Objections}

At least two objections arise against what I have striven to demonstrate over the course of this paper. I believe that both of these can be answered with a unifying response. The first of these objections is related to my opening claim that the theological-realist approach proves to be inconsistent with an Islamic understanding of an absolutely transcendent and ineffable God. I distinguished between the particular Islamic concept of God in question and the Christian tradition, the latter of which theological realism may in fact be consistent with (cf. Crisp).

The second of these objections is also related to the particular understanding of the Islamic God that I have invoked. I demonstrated that the methodological imports of Quine's ontology and concepts such as metaphysical realism cannot simply be applied to this concept of God. ${ }^{45}$ How then would this particular notion of God succeed in overcoming the parameters of ontological (and more generally, metaphysical) frameworks and inquiry? Such an understanding of God would seem to claim an ontological space immune from the criticisms of philosophy and metaphysics (Blackburn 2007).

Both of these objections turn on the particular notion of God that has been the oblique subject of this discussion. They both demand an explanation of a God who is believed to be absolutely transcendent and ineffable. In the former objection this demand would mean providing a further distinction between the Islamic and Christian concepts of God. This supplementary distinction must explain why theological realism (and Quine's ontological outlook) may prove amenable in the Christian tradition and not the Islamic one, despite whatever surface familiarity each tradition may have. In the latter objection this demand would mean explaining how the Islamic concept of God manages to transcend such parameters of ontological method and inquiry.

I anticipate meeting both of these demands by alluding to the ontological transcendence of God in the Islamic tradition (the kind that I have referred to throughout my paper). Traditional metaphysicians that operated within Islamic theology espoused an ontological doctrine that purported a classification of everything that exists. ${ }^{46}$ Simply put, all that exists is created-with the exception of God. This classification plainly exempted God from everything else. It was a primary distinction made between God (the creator) and the rest of existence (the creation). Therefore, this outlook sought to initiate an ontological categorization to determine what there is 
(creation) without in the course also categorizing (or including) God (the creator). This was no mistake since the God in question could not in any sense be confined by the parameters of ontological investigation and, more broadly, human cognitive (and semantic) endeavour in all its glory. Any attempt at doing so would result in a plethora of doctrinal issues that would fundamentally distort the conception of God in the minds of those who believed in Him. Accordingly, ontological investigation (and metaphysical pursuit, more generally) within the Islamic tradition did not seek to determine what there is but rather what has been created. God could not be incorporated by such intellectual pursuits since He ontologically transcends all creation in a manner that is absolute.

This particular ontological transcendence, I believe, serves as a response to both of the objections flagged earlier. With regards to the former objection, Christians too would agree that a theological-realist approach is inconsistent with the absolute ontological transcendence of God. This would mean to say that if Christians construe the description of God as 'absolutely transcendent and ineffable' as being ontologically transcendent, then they would concede to an inconsistency between this understanding of a God and theological realism. Moreover, this would mean that they acknowledge the methodological limits of Quine's ontological outlook, which is responsible for much (if not all) of this inconsistency. However, if such ontological transcendence is foregone by Christians, then theological realism may prove to be amenable with their doctrine after all.

With regard to the second objection, finally, I think it is evident that if the ontological transcendence of God is upheld, then it becomes a means of overcoming the parameters of naturalistic ontological frameworks such as Quine's. If God is conceived as being ontologically (and semantically) transcendent, then He would supersede the confines of any ontological method and inquiry. I concede that one of the eccentric consequences ${ }^{47}$ of this position would be the claim to absolute ontological distinction, namely, immunity from philosophical and metaphysical inquiry and criticism.

\section{Conclusion}

I have shown how Quine's ontological theses variously bear a primary connection with each of the two readings of metaphysical (theological) realism. Quine's ontological theses in this sense act as a prerequisite which both the readings qualify. His naturalistic outlook itself proves to be the source of inconsistency between metaphysical realism and the Islamic understanding of an absolute transcendent and ineffable God. In other words, if Quine's 
ontological outlook were to be viewed independent of it being a prerequisite to any other theory, it would act as the substrate that is responsible for the inconsistencies which arise when applied to a particular conception of the divine. More broadly, I considered the influence of his philosophy of language upon his ontology and the overarching influence of his predominant naturalistic outlook on his philosophical attitude in general.

\section{Endnotes}

1. "This should also underline the point that the analytic theology I have in mind is analytic Christian theology" (Crisp 2009, 43)

2. "There are two sorts of issues that face the theologian considering theological method. First, there are procedural concerns encapsulated in the question, 'How should we go about doing theology?' Then there are material concerns, expressed in the query 'What is doctrine such and such all about? What are its contours, its central aspects; how can we make sense of it (to the extent we can make sense of it)?' How one thinks about matters of theological method, which theological approach or 'school' one aligns oneself with-these are matters that shape one's academic outputs and, as a consequence, one's academic career. So this is a vital matter for theologians of all stripes to consider, analytic theologians included" (Crisp 2011, 472).

3. "Analytic theology as an enterprise stands or falls with the viability of its ambitions and with the practical value of trying to do theology in a way that conforms to the prescriptions that characterize analytic philosophical writing" (Rea 2009, 7); "As I have characterized analytic theology, it is primarily a faith-seeking-understanding project, where 'metaphysical' analysis is the means by which theologians make sense of what they already believe" (Crisp 2009, 51); "It is, from one point of view, merely the appropriating of the methods and literature in current philosophical theology by theologians-knocking down the dividing wall and welcoming in those analytics interested in theology in the hope that they may make a properly theological contribution" (Crisp 2011, 472); "In other words, while the goal of an analytic theologian may be to gain further, objective understanding of Christian doctrine..." (Macdonald 2014, 55).

4. "Moreover, many if not most analytic theologians are 'realist': broadly speaking, they treat their commitments as expressive of real, objective theological truth, and investigate that truth using the tools of analytic philosophical in- 
quiry. Amongst them any theological convictions that they hold, therefore, is the further, grounding conviction that, in Oliver Crisp's words, 'there is such a thing as truth (about Christian doctrine) and that human beings are capable of understanding what that truth is"' (Macdonald 2014, 38). "I also think that theologians ought to be realists about the world in some (modest) sense: there really is a world beyond our minds, with which we have contact, and which we can say things about-world God has created and sustains" (Crisp 2011, 476).

5. It should be noted that, according to Crisp, analytic theology is accommodating towards various methodological approaches. For instance, he suggests: (1) "It seems to me that analytic theology is entirely consistent with either a substantive or procedural use of reason" (Crisp 2009, 42). Furthermore, he states: (2) "It seems to me that analytic theology, at least as I understand this method, is compatible with a range of theories of truth" (Crisp 2009, 46-47). In this 'range of theories of truth' he includes the following: (a) the deflationary theory of truth, (b) the epistemic theory of truth, and (c) the correspondence theory of truth. However, despite demonstrating that these theories of truth are in some way compatible with analytic theology, he tends to give preference to the correspondence theory over others. "I say the analytic theologian should adopt a correspondence theory of truth, where a proposition is true just in case it corresponds to some fact about the world. I also think that theologians ought to be realists about the world in some (modest) sense: there really is a world beyond our minds, with which we have contact, and which we can say things about-a world God has created and sustains" (Crisp 2011, 476). Furthermore, Rea disassociates any formal connection between analytic theology and epistemological theories: "As I said earlier, analytic theology as such carries no commitment to substantive theories about truth or epistemology" (Rea 2009, 8).

6. "Analytic theology works best as a robust form of speculative or dogmatic theology; and as a robust form of speculative or dogmatic theology, it needs to be firmly grounded in a realist metaphysics and epistemology, or a fundamental commitment to the objectivity and (at least partial) cognitive accessibility of divine reality and truth" (Macdonald 2014, 54-55).

7. This understanding of an Islamic God was one that I had borrowed from an illustrious twelfth-century Islamic theologian by name of al-Ghazali (10581111). My reference to al-Ghazali's understanding of God (in the Islamic tradition) was not one that I anticipated would present a mainstream view. In fact, the sheer theological diversity that exists in the Islamic theological tradition is sufficient proof in demonstrating the unlikeliness of any unanimous agreement on the matter. More broadly, there appears to be very little literature available on how various understandings of doctrines within the Islamic tradition are received by contemporary (analytic) philosophy and 
vice versa. I believe al-Ghazali's notion of an unknowable God who is equally ineffable and wholly mysterious proves to manifest a novel understanding when observed in light of the applications of contemporary philosophical methods (i.e. in analytic theology). From among al-Ghazālís theological views regarding God, here is an excerpt that bears a significant relevance to the specific notion of God that I shall adopt:

God does not inhere in anything, and nothing inheres in Him. He is exalted above being contained by space, and too holy to be bounded by time; on the contrary, He existed before He created time and space. He now has [the attributes] by which He was [previously characterized], and is distinguished from His creatures by His attributes. There is not in His essence what is other than He, nor in what is other than He is there [anything of] His essence. He is exalted above change [of state] and movement. Originated things do not inhere [or subsist] in Him, and accidental [events] do not befall Him. Rather, He does not cease; through the qualities of His majesty He is beyond cessation, and through the attributes of His perfection He is independent of [or does not require] any further increase of perfection. (al-Ghazālì 2014, 110)

The distinguishing feature which sits at the heart of al-Ghazālīs belief of God is that $\mathrm{He}$ is unknowable. Although one may be able to detect subtle indications of unknowability from the excerpt above, I find that Burrell (1987) has expressed this in a more evident manner:

Given the fact that "God is a being necessarily existing of Himself (al-mawjud al-wajib al-wujud bi-dhatihi)" (Maqsad 47, M 342-43), it should be clear that this "peculiar divine property belongs only to God and only God knows it." Moreover "it is inconceivable that anyone know it save Him or one who is His like, since He has no like, no other knows it." On such an account, "only God knows God" (ibid.). So the resources of philosophy confirm God's uniqueness or tawhid: the utter distinction of the One from all else: "everything the exercise of which is possible," which does in fact exist from that One "according to the best ways of order and perfection" (Maqsad 47, M 342). (Burrell 1987, 181)

It is this ineffable view of God that I have argued refuses to concur with the two components of realism (metaphysical and epistemic). I proposed that when an absolute transcendent God who is believed to be ineffable is approached with a realist outlook (as explained here) then both of the 
components which constitute this realism prove to strip this God from His transcendence. This is to say that both components which constitute a realist outlook (adopted by most analytic theologians) along with the two binary readings of metaphysical (theological) realism demonstrate to be inconsistent with an Islamic understanding of an absolute transcendent and ineffable God.

8. A collective understanding of these would thus give way for the possibility of God-talk and divine reality in a manner that was conceived of as being objective. This objectivity would permit accurate apprehension in being epistemologically able to know God. Moreover, it would succeed in construing religion (in general) as a meaningful component of people's lives that possesses integral value. This would primarily be down to the ability to make a successful correspondence between what was being upheld (as beliefs) and their referents. If such a method were precluded in apprehending religious dogmas (if that remained possible), it would result in the contrary, namely a form of subjectivism and/or scepticism.

...the possibility to engage in God-talk and with divine reality, objectively. This objectivity would make way for an apprehension of God and construe religion as a meaningful part of people's lives. It would provide a successful correspondence between upheld beliefs and their referents. Any digression from this methodological outlook would potentially result in some form of theological subjectivism and/or scepticism. These views would include theologising either in a manner which fails to objectively correspond to the God or divine reality in question, or while suspending all thought and speech on the grounds of epistemic closure. It would sever the believer from what she so devotedly invests her conviction in. (Ahsan 2017, 103104)

9. "The former of these (metaphysical theological realism) would maintain that since there exists a mind-independent divine reality, it is one which either includes or is identical with God. Depending on which one of the two alternatives is adopted, this mind-independent reality would either be one which encompasses God in the sense that He is contained in/by it, or it would be one that actually is God" (Ahsan 2017, 105).

10. "Pantheism is a metaphysical and religious position. Broadly defined, it is the view that (1) 'God is everything and everything is God ... the world is either identical with God or in some way a self-expression of his nature' (Owen, $1971,74)$. Similarly, it is the view that (2) everything that exists constitutes a 'unity' and this all-inclusive unity is in some sense divine (MacIntyre 1967, 34). A slightly more specific definition is given by Owen, who says (3) 'Pan- 
theism . . . signifies the belief that every existing entity is, only one Being; and that all other forms of reality are either modes (or appearances) of it or identical with it' $(1971,65)$. Even with these definitions there is dispute as to just how pantheism is to be understood and who is and is not a pantheist" (Levine 2010, 338).

11. The Quinean criterion of ontological commitment, as we have seen, is a methodological (contrast substantive) yardstick for ontology. Methodologically careful ontologists like Peter van Inwagen have suggested that we take the label 'criterion of ontological commitment' as naming, rather than a foolproof procedure, a heuristic strategy to conduct ontological disputes (Berto and Plebani 2015, 40).

12. Quine's involvement in the relatively new and expanding analytic tradition of philosophy during the second half of the twentieth century can hardly go unnoticed. His substantial contributions in analytic philosophy proficiently bear testimony to this claim:

During his 65-year-long career he published over twenty books and well over a hundred articles, having made significant contributions to a large number of fields within philosophy, including epistemology, metaphysics, logic, set theory, philosophy of logic, philosophy of language, and philosophy of science. It is uncontroversial that Quine was one of the most influential philosophers of the twentieth century, along with Carnap, Russell, and Wittgenstein. (Harman and Lepore 2014, 2)

During his stellar sixty-five-year-long career he published twenty some books and scores of articles, and he lectured in six languages on six continents. He made major contributions to a large number of fields within philosophy, including epistemology, metaphysics, metaethics, logic, set theory, philosophy of logic, philosophy of language, philosophy of science, and philosophy of mind. In recognition of his many contributions, Quine was awarded eighteen honorary degrees and numerous other honors, prizes, and medals. Without doubt, Quine was one of the most gifted and influential analytic philosophers of the twentieth century and belongs squarely in the ranks of Carnap, Russell, and Wittgenstein. (Gibson 2004, 6)

More noticeably however, his scholarly fascination proved to be more intimate with one of the profoundest areas of philosophy, namely, ontology. His intellectual preoccupation with ontology can be appreciated from his scholarly devotion to this area that spanned a considerable portion of his life. “Ontology played a very large role in Quine's philosophy and was one of his 
major preoccupations from the early 30's to the end of his life ... As can be seen from the bibliography in the Schilpp volume, he published extensively on ontology perhaps more than on any other specific philosophical subject" (Chateaubriand 2003, 41). More importantly, however, his contributions in the domain of ontology tended to serve as a rudimentary groundwork for intellectual exchanges that took place in field of analytic metaphysics ("And Quine's work on ontology provided a basic framework for most of the discussions of ontology in analytic philosophy in the second half of the Twentieth Century": Chateaubriand 2003, 41). Of course, Quine was a renowned systematic philosopher (Gibson 2004, 6); having reached the height of his intellectual profession, Quine was very much considered a 'system builder'.

Quine is a system builder, whose system dispenses with many of the presuppositions at work in mainstream analytical philosophy of the past forty years; unless one has studied his system as a whole, one will not see the motivation or justification behind its particular components. (Kemp, 2014, 70)

-or, alternatively put, an 'agenda-setter': "Most agree that W.V. Quine (1908-2000) was the principal agenda-setter in post-World War II philosophy of language and related fields" (Kemp 2014, 69). Such theoretical manufacturing should not to be confined to Quine's substantial involvement in the revival of metaphysics alone, but should rather be seen as encompassing the more elusive manifestations throughout analytic philosophy. It is, however, rather difficult to be able to entirely appreciate the scope of which such manifestations may become glaring apparent. Kemp (2013) touches on this very matter by suggesting that,

Quine is a system builder, whose system dispenses with many of the presuppositions at work in mainstream analytical philosophy of the past forty years; unless one has studied his system as a whole, one will not see the motivation or justification behind its particular components. But that is a big, book-length topic. (Kemp, 2013, 70)

It therefore appears that the vastness of breadth and, more importantly, the depth that is involved in being able to appreciate the specifics of Quine's generic impact on analytic philosophy is a monumental task. However, when specifying this generic impact, particularly in virtue of his ontological method, which is what we are primarily concerned with over here, we manage to obtain some appreciation of Kemp's statement. Prior to drawing on Quine's ontology, it should be noted that my focus here is not exclusively restricted to revealing the kind of influence Quine had on ontology and its method - at least not in isolation. More precisely rather, my aim is to draw on the influ- 
ence of Quine's ontology in establishing that his methodological approach (in ontology) is a prerequisite of metaphysical realism.

13. Quine's naturalism committed him to:

1. There is no first philosophy - no experiential or a priori foundation outside of science upon which science can be justified or rationally reconstructed.

2. It is up to science to tell us what there is (ontology) and how we know it (epistemology). Further, the currently best science advocates physicalism and empiricism. (Harman and Lepore, 2014, 2)

14. "Furthermore, according to Quine, the currently best science advocates a physicalist ontology and an empiricist epistemology. So Quine the naturalist is also Quine the physicalist and Quine the empiricist." (Gibson, 2004, 6)

15. "A refinement of materialism introduced because not all physical phenomena are material. Physicalism assumes that physical science can encompass everything in the world, and that ultimately everything in the world can be explained through physics. It is possible to reduce any scientific predicate to a physical predicate. The word was introduced by the logical positivists for the claim that all scientific statements could be translated into statements about physical or observable objects. In this sense, physicalism is close to scientism, which claims that any language that can not be reduced to scientific language is defective." (Bunnin and Yu, 2004, 530)

16. Since not all physical phenomena are considered as being material in this case. However, Quine's 'refinement' also extends to the term 'physicalism' itself, since for him; ontological physicalism is constituted of more than just physical states and objects. He boldly includes the abstract objects of mathematics in the constitution of physicalism.

17. "When the context is philosophy of language, the term 'physicalism' signals his rejection of mentalistic semantics" (Gibson 2004, 6)

18. "When the context is philosophy of mind, the term signals his rejection of mind-body dualism" (Gibson 2004, 6).

19. "Furthermore, despite the fact he holds that logic is revisable in the light of empirical inquiries, Quine (who was a distinguished logician) still assigns logic a central place in his philosophy of language. For example, he holds that questions of ontology are dependent on questions of logic since 'to be is to be the value of a variable' - that is, the ontological commitments of a theory are dependent on its logical structure since they concern the kinds of thing whose existence is logically required for the truth of the theory" (Baldwin 2006, 77).

20. "The first generation under examination here, that of Bertrand Russell and G.E. Moore, both in their twenties by 1900, are credited with the decisive 
break away from idealism at the turn of the century" (Akehurst 2010, 2). And, further: "The fact seems to be that all our a priori knowledge is concerned with entities which do not, properly speaking, exist, either in the mental or in the physical world" (Russell 2008, 60). The exact reasons for why they espoused a deep intellectual resentment for the idealist notion as a whole and the birth of analytic philosophy as its reaction, I believe, cannot be confined to merely academic justifications. In fact, aside from the academic explanations for why there arose such antipathy and a reaction to it, there appears to be have existed prominent socio-political drives that are seldom spoken of by historians.

Analytic philosophy emerged and came to dominance in Britain against the backdrop of some of the most traumatic events of the twentieth century. In the time between analytic philosophy's emergence in Cambridge in the first decade of the century and its achievement of institutional dominance in Britain in the 1950s, two new ideologies, Marxist-Leninism and fascism, made dramatic appearances on the world stage, and Europe saw its two bloodiest wars in history. Between 1940 and 1945, many of the most significant British analysts of the twentieth century were also soldiers, intelligence officers or code breakers. What we find in the work of these thinkers are attempts to relate their philosophical enterprise to the chaotic times in which they lived.

Yet these reflections and beliefs have been largely ignored by historians. This project reveals two previously unacknowledged themes in analytic discussion. First, as the quotations from Lord Russell, and Professors Ryle and Hare at the top of this introduction illustrate, there was a consistently held belief among these early generations of analytic philosophers that a post-Kantian tradition of continental philosophy was the direct source of fascist ideology. I will examine these quotations in far more detail later, but what we can see here is the condemnation of Nietzsche, Hegel, and, in the quotation from Hare romantic philosophy, as being in some way the "ancestors of fascism", to use Russell's phrase. This belief was generalized as the analytic philosophers witnessed what they believed to be Germany's corruption of the European (though not the British) mind, helping to form the notion of a dangerous "continental philosophy", characterized as philosophically inadequate, politically aggressive, and irrational. (Akehurst 2010, 3) 
These diverse socio-political drives apparently played into much of the intense antagonism and the reactions which consequently followed in the guise of analytic philosophy. There is very little doubt that the subjugation of such historical intricacies created a somewhat misrepresented understanding of the birth of analytic philosophy. Nonetheless, as unfortunate and striking as this may appear to be, it is a discussion that is undeniably worth having at another juncture.

21. This for Russell was "the intermediary of any process of inference or any knowledge of truths" (Russell 2008, 33).

22. "Knowledge of things, when it is of the kind we call knowledge by acquaintance, is essentially simpler than any knowledge of truths, and logically independent of knowledge of truths, though it would be rash to assume that human beings ever, in fact, have acquaintance with things without at the same time knowing some truth about them. Knowledge of things by description, on the contrary, always involves, as we shall find in the course of the present chapter, some knowledge of truths as its source and ground" (Russell 2008, 33).

23. "We shall say that we have acquaintance with anything of which we are directly aware, without the intermediary of any process of inference or any knowledge of truths. Thus in the presence of my table I am acquainted with the sense-data that make up the appearance of my table-its colour, shape, hardness, smoothness, etc.; all these are things of which I am immediately conscious when I am seeing and touching my table" (Russell 2008, 33).

24. "Some of our beliefs turn out to be erroneous, and therefore it becomes necessary to consider how, if at all, we can distinguish knowledge from error. This problem does not arise with regard to knowledge by acquaintance, for, whatever may be the object of acquaintance, even in dreams and hallucinations, there is no error involved so long as we do not go beyond the immediate object: error can only arise when we regard the immediate object, i.e. the sense-datum, as the mark of some physical object" (Russell 2008, 73).

25. "Let us give the name of 'sense-data' to the things that are immediately known in sensation: such things as colours, sounds, smells, hardnesses, roughnesses, and so on" (Russell 2008, 12).

26. "All our knowledge, both knowledge of things and knowledge of truths, rests upon acquaintance as its foundation" (Russell, 2008, 34).

27. "The fundamental principle in the analysis of propositions containing descriptions is this: Every proposition which we can understand must be composed wholly of constituents with which we are acquainted" (Russell 2008, 40).

28. "We must attach some meaning to the words we use, if we are to speak significantly and not utter mere noise; and the meaning we attach to our words must be something with which we are acquainted. Thus when, for example, 
we make a statement about Julius Caesar, it is plain that Julius Caesar himself is not before our minds, since we are not acquainted with him. We have in mind some description of Julius Caesar: 'the man who was assassinated on the Ides of March', 'the founder of the Roman Empire', or, merely 'the man whose name was Julius Caesar'. (In this last description, Julius Caesar is a noise or shape with which we are acquainted.) Thus our statement does not mean quite what it seems to mean, but means something involving, instead of Julius Caesar, some description of him which is composed wholly of particulars and universals with which we are acquainted" (Russell 2008, 40).

29. Quine discusses in his paper-aptly entitled 'Epistemology Naturalized' knowledge of the natural world which includes an empiricist and scientific approach. He attempts to reduce all natural knowledge to sense experience, perhaps like the way in which he (and others) endeavoured to reduce mathematics to logic.

30. I use this term with 'Logical Empiricism' and the 'Verification Principle' in mind.

31. I acknowledge that this circularity may pose as a non-starter-at least for those who are not in any way sympathetic to Quine's position. Moreover, this mode of thought would also fail to get off the ground for those who are not in any way inclined towards naturalism and the authority of science. Consequently, if this is an issue which sits at the heart of the debate then we needn't spend time on establishing how Quine's ontology is a prerequisite for metaphysical (theological) realism and how/why it proves to be inconsistent with a particular concept of an Islamic God. However, my approach is somewhat different. I anticipate highlighting theological inconsistencies that are primarily motived by analytic philosophical methods. The way in which I hope to achieve this is by beginning with a particular theological doctrine (namely, a particular concept of God in the Islamic tradition) and subsequently identifying the analytic philosophical methods (namely, metaphysical realism) that fail to be amenable with the doctrine they are applied to. This approach may appear unconventional, since I begin with a theological doctrine and only then investigate the analytic philosophical methods it is subjected to. It thus seems like I take the theological matters for granted. What would have been more rational, by this account, is to begin with epistemological issues that first determine the existence and truth of such theological matters, before subjecting them to the kind of analysis in question. Yet Crisp has suggested the following:

A second objection has to do with whether analytic theology is really a theological enterprise at all. Here a further point of clarification may help. As I have characterized analytic theology, it is primarily a faith-seeking-understanding project, where 'metaphysical' analysis 
is the means by which theologians make sense of what they already believe. In short, the main task of analytic theology as it has been characterized thus far is primarily metaphysical. If it is a project that deals with epistemological matters, these are secondary to its primary goal. So analytic theology does not address the question that has bedevilled much modern theology in the wake of Kant's Copernican Revolution in philosophy, namely: how is knowledge of God possible? It is much more concerned with other kinds of questions. How can the doctrine of the Trinity be coherent? What does it mean to say 'Christ died for our sins'? How is eschatology related to God and time? Taken in this way, analytic theology seems a lot more traditional than it might appear at first glance. For these are precisely the sorts of questions that classical theologians addressed themselves to. But this will not be a recommendation of analytic theology to at least two sorts of people. The first sort is the person who maintains that theology is really nothing more than a branch of philosophy. If this is the case, then the whole idea of analytic theology is misguided, because it assumes that theology is a distinct discipline from philosophy. But I think this is mistaken. Theology is a variegated and complex discipline that is distinct from philosophy, although both disciplines share overlapping concerns. It would be wrong to think that theology may be reduced to philosophy because theologians make use of philosophical tools and notions, just as it would be wrong to think that biology can be reduced to physics, just because biologists make use of physics in biological science.

A second sort of person will object that the characterization of analytic theology as principally a metaphysical, not epistemological enterprise is to put the theological cart before the horse. One cannot begin to ask questions about the nature of God before establishing whether we are able to talk about the nature of God in any meaningful sense. This, of course, is one way in which the Kantian spirit of much modern theology manifests itself. But, as Nicholas Wolterstorff points out,

If one believes that one's car is in good running order, one does not spend the whole day tinkering under the hood to determine whether it could possibly be in good running order, and if so, how. One gets in and drives off. Along the way one might discuss with one's passengers 
how it is that this old car runs-especially if they thought it wouldn't. (Crisp 2009, 62-63)

32. "The notion of observation is subject to a curious internal tension. Observation affords the sensory evidence for scientific theory, and sensation is private. Yet observation must be shared if it is to provide the common ground where scientists can resolve their disagreements. The observation must be the distillate, somehow, of what is publicly relevant in the private sensations of present witnesses. This delicate process of distillation is already accomplished, happily, in our most rudimentary learning of language. One learns the word 'blue' from another speaker, in the presence of something blue. The other speaker has learned to associate the word with whatever inscrutable sensation it may be that such an object induces in him, and one now learns to associate the word with the sensation, same or different, that the object induces in oneself. All agree in calling the object blue, and even in calling their sensations blue" (Quine in Johnsen 2014, 333-334).

33. "The notion of observation is subject to a curious internal tension. Observation affords the sensory evidence for scientific theory, and sensation is private. Yet observation must be shared if it is to provide the common ground where scientists can resolve their disagreements. ... What are observations? They are visual, auditory, tactual, olfactory. They are sensory, evidently, and thus subjective. Yet it was crucial to the use of observations, both as evidence and as semantical reference points, that they be socially shared. Should we say then that the observation is not the sensation after all, but the shared environmental circumstances? No, for there is no presumption of intersubjective agreement about the environing situation either; two men will assess it differently, partly because of noticing different features and partly because of entertaining different theories.... [E]vidential support of science...comes now to be seen as a relation of stimulation to scientific theory. Theory consists of sentences, or is couched in them; and logic connects sentences to sentences. What we need, then, as initial links in those connecting chains, are some sentences that are directly and firmly associated with our stimulations...." (Quine in Johnsen 2014, 333-334).

34. "A sentence is observational insofar as its truth value, on any occasion, would be agreed to by just about any member of the speech community witnessing the occasion. ... The definition speaks of joint witnessing. In a more precise statement, it would speak of witnesses subject to receptually similar impingements ... [where] episodes are receptually similar to the degree that the total set of sensory receptors that are triggered on the one occasion approximates the set triggered on the other occasion" (Quine in Johnsen 2014, 335-336).

35. "An empirical test, in extreme cases, will consist in finding some observation categorical that, according to the theory, should be true and then seeing whether falsifying instances can be found. It is just the uncontroversial na- 
ture of observation sentences that fits them to play this role" (Hylton 2004, 118).

36. Since, for Quine, the edifice of our knowledge hinges on the foundations of science.

37. "What is important for us is that reference, for Quine, is not the fundamental relation between language and the world; it is not the means by which language acquires its empirical content and comes to be about the world. That relation is, rather, the relation between an observation sentence and the situations that typically lead to the sorts of stimulations under which the sentence is uttered or commands assent when uttered by another. Reference, on Quine's account, is a relation between language, or some linguistic expressions, and the world, just not one that is fundamental in the sense we have indicated" (Hylton 2004, 121).

38. "Reference, for Quine, is a derivative notion; the fundamental notion is that of the relation between a complete utterance and the circumstances that make it true" (Hylton 2004, 120).

39. "Reference, for Quine, is thus not the fundamental relation that language has to the world. It is, however, a notion of great importance. Our cognitive discourse is, or aims to be, about the world; a particular utterance is, or aims to be, about some portion of the world, typically about some object or objects. That reference is not fundamental means that there is an explanation, in other terms, of how it comes about; it does not mean that reference is unimportant. And for Quine an understanding of the referential capacities of our cognitive language is the crucial step in the clarification of that language" (Hylton 2004, 122).

40. "An open sentence is obtained from a sentence containing names by replacing one or more of those names by a variable, that is, a lowercase italicized letter from near the end of the alphabet. Thus we obtain ' $x$ is human' from 'Socrates is human', 'If $\mathrm{x}$ is human, then $\mathrm{x}$ is mortal' from 'If Socrates is human, then Socrates is mortal', and so on. A name need not be replaced at every occurrence, nor need every name be replaced. An open sentence contains one or more variables and may also contain names. An open sentence, clearly, is not true or false as it stands; it is, however, true or false of each object (or of each pair of objects, if it contains two distinct variables, and so on)" (Hylton 2004, 122-123).

41. The dilemma this raised for Quine was how are we to make any sense of true propositions that negate the existence of certain objects or entities, such as 'Mermaids do not exist'. Such propositions oblige us to ontologically commit to the very objects or entities they set out to negate, in this case 'mermaids'.

42. As opposed to non-cognitive mental states such as desires that lead us to act, instead of understanding a situation. Thus, desires in this sense would be considered as being unrelated to a representation and associated to action. 
43. Namely Sartre, since Peter Van Inwagen writes that "there is no God, Sartre contends, for precisely the reason that God's being would be an impossible amalgam of être en-soi (God is immutable and eternal) and être pour-soi (God is a free, conscious agent)" (Van Inwagen 2014, 55).

44. This unnecessary duplication of realities would not merely be one that implies that it is beyond necessity but rather one that is false.

45. I have shown this in my previous work (Ahsan 2017) by revealing the consequences it would have on this particular concept of God in the Islamic tradition.

46. "Within what one may term the primary Basrian tradition, i.e., that common ground from which derive the shared elements both of the Mu' tazilite tradition that follows from 'the Two Masters', abû 'Alî al-Ğubbầî and abû Hâšim, and of the Ašarite tradition, all that exists, that has being or existence $(w u \breve{g} \hat{u} d)$ as an entity or thing-itself ( $\left.\underline{d} \hat{a} t, \check{s}^{\prime} y^{\prime}\right)$ other than God is created and corporeal. Created being is divided into two fundamental categories: the atoms (ğawâhir) and the accidents ('árâd l) that inhere in them. These two, distinguished ontologically by the mode of their existence (al-kayfîyatu fî l-wu ğud), viz., that the former occpuies space (tahayyaza) and that the latter does not, are the primary entities, in the proper Aristotelian sense of the term. It is they that in the strictest sense are said to exist and to have being and it is they which are most truly said to be 'essences'/things-themselves (dawât, 'ašyâ'): things that are the subject of predications (muhbarun 'anhâ) but are not themselves said of anything else" (Frank 1978, 39-40).

47. This means to allude to an unconventional approach in comparison to the analytic methodological approaches of philosophy.

\section{References}

Ahsan, A. (2017). "A Realist Approach in Analytic Theology and the Islamic Tradition." Philosophy and Theology 29, no. 1: 101-132.

Akehurst, T. (2010). The Cultural Politics of Analytic philosophy. London [u.a.]: Continuum.

Berto, F. and Plebani, M. (2015). Ontology and Metaontology: A Contemporary Guide. London: Bloomsbury Publishing.

Bertrand, R. (2008). The Problems of Philosophy. USA: Arc Manor.

Blackburn, S. (2007). "Religion and Ontology," in Realism and Religion: Philosophical and Theological Perspectives, edited by A. Moore and M. Scott, 47-59. Hampshire: Ashgate Publishing Limited.

Bunnin, N. and Yu, J. (2009). The Blackwell Dictionary of Western Philosophy. Oxford: Wiley-Blackwell. 
Burrell, D. (1987). “The Unknowability of God in Al-Ghazali.” Religious Studies 23, no. 2: $171-182$.

Chateaubriand, O. (2003). "Quine and Ontology." Principia 7, nos. 1-2: 41-74.

Crisp, O. (2011). "On Analytic Theology." In Analytic Theology: New Essays in the Philosophy of Theology, edited by O. Crisp and M. Rea, 33-53. Oxford: Oxford University Press.

Crisp, O. (2011). "Analytic Theology." The Expository Times 122, no. 10: 469-477.

Decock, L. (2004). "Inception of Quine's Ontology." History and Philosophy of Logic 25, no. 2: 111-129.

Fogelin, R. (2004). “Aspects of Quine's Naturalized Epistemology" In The Cambridge Companion to Quine, edited by R. Gibson, 18-46. Cambridge: Cambridge University Press.

Frank, R. (1978). Beings and Their Attributes. Albany: State University of New York Press.

Gibson, R. (2004). "Willard Van Orman Quine." In The Cambridge Companion to Quine, edited by R. Gibson, 1-18. Cambridge: Cambridge University Press.

al-Ghazālī, A.H. (2014). "Ghazālī‘s Ash`arī Creed.” Translated by W. Montgomery Watt. In Islamic Theological Themes: A Primary Source Reader, edited by J. Renard, 109-113. Berkeley: University of California Press.

Gjelsvik, O. (2014). "Quine on Observationality." In A Companion to W.V.O. Quine, edited by G. Harman and E. Lepore, 313-332. Chichester: John Wiley \& Sons Ltd.

Harman, G. and Lepore, E. (2017). "Introduction: Life and Work." In A Companion to W.V.O. Quine, edited by G. Harman and E. Lepore, 1-15. Chichester: John Wiley \& Sons Ltd.

Hylton, P. (2004). “Quine on Reference and Ontology." In The Cambridge Companion to Quine, edited by R. Gibson, 115-150. Cambridge: Cambridge University Press.

Hylton, P. (2014). “Quine's Naturalism Revisited." In A Companion to W.V.O. Quine, edited by G. Harman and E. Lepore, 148-162. Chichester: John Wiley \& Sons Ltd.

Jacquette, D. (2014). Ontology. Abingdon, Oxon: Routledge.

Johnsen, B. (2014). “Observation.” In A Companion to W.V.O. Quine, edited by G. Harman and E. Lepore, 333-349. Chichester: John Wiley \& Sons Ltd.

Kelly, T. (2014). “Quine and Epistemology." In A Companion to W.V.O. Quine, edited by G. Harman and E. Lepore, 17-37. Chichester: John Wiley \& Sons Ltd.

Kemp, G. (2014). "Quine’s Relationship with Analytic Philosophy.” In A Companion to W.V.O. Quine, edited by G. Harman and E. Lepore, 69-88. Chichester: John Wiley \& Sons Ltd.

Macdonald, P. (2008). "In Defence of a Realist Interpretation of Theology." Religious Studies 44, no. 1: 23-42. 
Macdonald, P. (2014). "Analytic Theology: A Summary, Evaluation, and Defense." Modern Theology 30, no. 1: 32-65.

McGinn, C. (2003). Logical Properties. Oxford: Clarendon Press.

Michael, L. (2010). "Pantheism.” In A Companion to Philosophy of Religion, edited by C. Taliaferro, Draper and Quinn, 337-347. 2nd ed. Oxford: Blackwell Publishing.

Rea, M. (2007). Realism in Theology and Metaphysics. In Belief and Metaphysics, edited by Candler and C. Cunningham, 323-344. London: SCM Press.

Rea, M. (2011). "Introduction.” In Analytic Theology: New Essays in the Philosophy of Theology, edited by O. Crisp and M. Rea, 1-30. Oxford: Oxford University Press.

Preston, A. (2010). Analytic Philosophy. London: Continuum.

Raley, Y. (2007). “Ontology, Commitment, and Quine's Criterion.” Philosophia Mathematica 15, no. 3: 271-290.

Sennet, A. and Fisher, T. (2014). "Quine on Paraphrase and Regimentation." In: $A$ Companion to W.V.O. Quine, edited by G. Harman and E. Lepore, 89-113. Chichester: John Wiley \& Sons Ltd.

Quine, W.V.O. (1969). “Epistemology Naturalized.” In Ontological Relativity and Other Essays. New York: Columbia University Press. 69-90.

Van Inwagen, P. (1998). “Meta-Ontology.” Erkenntnis 48: 233-250.

Van Inwagen, P. (2014). Existence. Cambridge: Cambridge University Press.

Weir, A. (2014). "Quine's Naturalism.” In A Companion to W.V.O. Quine, edited by G. Harman and E. Lepore, 114-147. Chichester: John Wiley \& Sons Ltd.

Westphal, M. (2001). Overcoming Onto-theology. New York: Fordham University Press.

Westphal, M. (2007). “The Importance of Overcoming Metaphysics for the Life of Faith.” Modern Theology 23, no. 2: 253-278.

Westphal, M. (2007). “Theological Anti-Realism.” In Realism and Religion: Philosophical and Theological Perspectives, edited by A. Moore and M. Scott, 131-145. Hampshire: Ashgate Publishing Limited.

Wolterstorff, N. (2011). "How Philosophical Theology Became Possible within the Analytic Tradition of Philosophy." In Analytic Theology: New Essays in the Philosophy of Theology, edited by O. Crisp and M. Rea, 155-168. Oxford: Oxford University Press. 